\title{
Social Studies of Science
}

http://sss.sagepub.com

\section{Environmental Justice and Expert Knowledge in the Wake of a Disaster Barbara L. Allen \\ Social Studies of Science 2007; 37; 103 \\ DOI: $10.1177 / 0306312706069431$}

The online version of this article can be found at:

http://sss.sagepub.com

\author{
Published by: \\ (s) SAGE Publications \\ http://www.sagepublications.com
}

Additional services and information for Social Studies of Science can be found at:

Email Alerts: http://sss.sagepub.com/cgi/alerts

Subscriptions: http://sss.sagepub.com/subscriptions

Reprints: http://www.sagepub.com/journalsReprints.nav

Permissions: http://www.sagepub.com/journalsPermissions.nav 


\title{
SSS
}

\section{Environmental Justice and Expert Knowledge in the Wake of a Disaster}

\author{
Barbara L.Allen
}

Keywords hazardous waste, Hurricane Katrina, public health, public science, public understanding of science

The aftermath of Hurricane Katrina provides an important lens into the various dimensions environmental justice in New Orleans. In particular, the hurricane served to highlight disparities in health and well-being that already existed in the region and to foreground the vulnerabilities of poor, working class, and minority communities. Disputes over local vs cosmopolitan knowledge and questions about whose science and whose knowledge 'counts' in the reclamation of the city play out in the politics of rebuilding this historic place.

The US environmental justice (EJ) movement of the past several decades, a hybrid of traditional environmental and social justice concerns, has primarily focused on two issues: (1) the siting and expansion of hazardous and undesirable facilities in poor and minority communities; and (2) the effort to remediate, relocate, and/or pay damages to members of poor and minority communities affected by pollution. Louisiana has been a focus of this movement, with citizens' groups fighting a variety of injustices from the siting of hazardous industries in minority communities to building affordable housing on superfund sites (Roberts \& Toffolon-Weiss, 2001).

A good example of the EJ movement is the activism that has taken place in Louisiana's Cancer Alley, an 85-mile stretch of the Mississippi River between New Orleans and Baton Rouge that is home to more than 130 petrochemical plants and petroleum processors interspersed between numerous rural, urban, and suburban communities. The public controversies that have played out in the region, largely driven by the citizens' desire to protect or clean up their environment, serve to illustrate intersections between EJ and science studies. In particular, the public understanding and use of science has played an important role in the various debates and has helped shape regulation, enforcement, and remediation (Allen, 2003). Science has often been used strategically as a weapon in the context of environmental controversy, with each side each having its own, often unequal, defenses. Furthermore, the integration of environmental issues with social justice concerns engendered a broader conception of what counts as a 
'good' environment and fostered heterogeneous scientific practices that encouraged public participation and the inclusion of local knowledge.

For purposes of showing how EJ and the public understanding and use of science converge in novel ways during a natural disaster, I will focus on three areas in the aftermath of Katrina. The first is public health concerns. These include questions about the kinds of hazards citizens are exposed to in the aftermath of a disaster and how they are protected or warned. They also include questions about the kind of work government agencies do to attenuate, measure, and communicate potential health impacts. Do these concerns reflect residents' local knowledge and practices? Are appropriate steps taken to insure that the poor and even illiterate populations are included? A second concern is the potential creation of environmental injustices through the disposal of disaster debris in inappropriate locations with improper remediation and indiscriminate mixing of hazardous and nonhazardous waste. The third concern has to do with racial and class disparities arising with the rebuilding of New Orleans that the media and the various commissions on Katrina have largely ignored. Has 'expertise' been used to de-politicize these issues? How might expert knowledge map onto the historical and cultural situatedness of local knowledge to create a more multiperspectival view of what an equitable rebuilding plan might look like?

\section{Public Health and the Right of 'Safe' Return}

After the hurricane there were endless reports of flooding on superfund sites and upending of oil storage tanks. The weeks of open sewage flow in the streets of New Orleans, combined with the decaying bodies of humans and animals, concerned many in the public health community. The final blow was the flooding of the city from Lake Ponchartrain, due to drainage canal breaches. The rush of water from the lake scraped about two feet of sediment from canal and lake bottoms, and re-deposited about 30 to 40 years of sediment, including old hazardous materials, in parts of the city. The black sediment originated from Louisiana's toxic industrial practices and pesticide use when little regulation was in force. ${ }^{1}$

The black sludge is apparent to anyone who has traveled through the previously flooded areas of the city. As it dries it forms a cracked, greyish 'moonscape'. Wilma Subra, an environmental scientist who has worked with many community groups in Louisiana sampled numerous sites around the metro area, and found elevated levels of heavy metals, with arsenic having particularly high levels in $92 \%$ of her samples. In the Lower Ninth Ward, for example, arsenic was 74 times the US Environmental Protection Agency (EPA) standard. ${ }^{2}$ While this might seem very high, the state of Louisiana has different standards than the Federal Government for arsenic: the same sample was only 2.5 times the state's allowable limit, giving the appearance of being less toxic. Subra also found evidence of many toxic chemicals associated with now-defunct polluting industries, such as creosote facilities.

Additionally, Subra discovered high levels of E. coli, salmonella, and other bacteria, which she and local environmental activists believed may 
have been responsible for workers' rashes and infections that were not responding to antibiotic treatment. 'Katrina cough' and respiratory illnesses were also prevalent in the city, due in part to the out-of-control growth of molds and mildews. But, 'the EPA has come out and said there is no acute impact to support our claim' (Subra interview). Furthermore, though the communities' data supported the EPA's, in many cases their 'safety' interpretations were quite different. According to Subra, a further problem with the toxic material was its dispersal through the air and through skin contact, thus raising the prospect of epidemics. The EPA and Federal Emergency Management Agency (FEMA) were reluctant to comment or act, according to Subra, because state officials were anxious to open up neighborhoods so that residents could return. Government agents were simply hoping it would rain and the material would simply wash away. It has rained and the sludge is still there - lots of it - and it is still very toxic (Subra interview).

When residents initially were allowed to return to their homes to inspect the damage - in some cases to clean up debris and search for salvageable possessions - local, state, and federal officials failed to recommend any precautions. Later, at the insistence of environmental groups, the EPA told returning residents not to come into contact with the sediment, and FEMA distributed a list of recommended protective gear (masks, gloves, tyvek suits, and so on). Unfortunately, if the residents could have afforded them, there was no place within 100 miles to buy any of those items, and non-profit organizations later began distributing them.

While wealthier homeowners hired people to clean and gut their homes, working class and poorer residents did the work themselves. Furthermore, many of the immigrant workers brought in by large government contractors to remove the debris wore little or no protective gear. Unprotected cleaning and demolition was thus highly risky in much of the city and the dangers were compounded by the lack of electricity, emergency dispatch systems, medical clinics, and running water.

Six months after the hurricane, I contacted public health officials and researchers, but many were reluctant to talk. One who did respond made some interesting observations, under the condition of anonymity. Health officials are in a difficult position. Six months after the devastation, only $20-25 \%$ of the city's residents have returned. Depending on what the federal government does about rebuilding homes and compensating residents, many officials are hopeful that 50 to $75 \%$ of former residents may eventually return. Publicity about public health issues would deter such repatriation, particularly for the large number of families with children who have not returned to the city.

Another concern about various state public health agencies has been their complicity with industry in the past. There are numerous examples of public health officials who have refused to address elevated lead levels in children living near oilfield waste sites (Allen, 2004). More recently, the state cancer collection agency, the Louisiana Tumor Registry, was taken to court by citizens and medical researchers who were trying to obtain zip-code specific information for rare cancers (such as pediatric cancers) occurring in 
residents living near petro-chemical facilities. The state has fought for a decade against releasing location-specific cancer data to the public, raising many questions among people living in industrial regions and near superfund sites (Allen, 2005).

Consequently, public trust in the state public health system to distribute accurate information has been compromised by years of questionable behavior. Trust in the source of information is paramount for insuring full participation in any public health and remediation efforts, and may be compromised by past actions (Irwin et al., 1996).

\section{Debris and Future Environmental Justice Claims}

Another potential EJ issue related to Katrina's aftermath is where the debris that is being removed from New Orleans is being dumped. Debris is piled on the curbs and in the street, in preparation for removal by contractors. Some people are hiring workers to scrape the sludge from their property so it can be removed with the debris. The heaps of discarded material include household waste, building products, cars, electronics, appliances, and the noxious sludge.

State maps of the allowable hurricane debris disposal areas show that sites have been re-opened which had been closed long ago for failing to meet federal standards. Many such sites can be described as swampland filled with material scraped off the street and of unknown composition. Some people made efforts to separate the waste into hazard categories, in order to facilitate environmentally sound removal, but their efforts were thwarted by the lack of leadership and sharing of information that plagued the cleanup effort. Local efforts to pursue sound cleanup practices were not adequately coordinated with the large corporate firms hired to remove debris, as large out-ofstate contractors hired by FEMA for waste removal would simply push the separated piles of debris together and cart them off to the dumpsite (Subra interview). Such disconnects between local and non-local knowledge have plagued the cleanup process and may create future superfund sites.

The present case is not the first time a hurricane's refuse created a toxic zone. The Agricultural Street landfill in New Orleans was one of the main sites for waste from Hurricane Betsy (1965). That landfill had been closed for years prior to the hurricane, due to complaints from local citizens, but the mountains of waste generated by Betsy led to its emergency re-opening. Fifteen years later the Federal Housing and Urban Development Agency (HUD) built affordable homes on the reclaimed landfill and sold them to African Americans. In 1990 it was designated a superfund site with a concentration of heavy metals many times the EPA standard. Government officials declared to residents that 'there was no apparent public hazard' (Toffolon-Weiss \& Roberts, 2005: 87). It became a legendary EJ battle and the residents, citing health problems, are still fighting for relocation.

I received an email early in 2006 from a high school student living in a rural parish west of New Orleans along the Mississippi River (an area EJ advocates have renamed Cancer Alley). About a month after Katrina, an 
old landfill near her house began to receive foul-smelling waste. She took samples of the 'black ooze' to her chemistry class as a project and contacted the state Department of Environmental Quality, who told her that the landfill was only accepting construction waste and the smell she described was probably decaying gypsum board. She then contacted an independent scientist to help her analyze the sample. I suspect that her story will be repeated many times across south Louisiana, as marginal waste sites fill with debris from destroyed homes and businesses.

\section{Voids of Science and Silence in Race, Class, and Rebuilding Issues}

Much has been written in the press regarding race, class, and rebuilding. Pundits have predicted everything from the developer-inspired Disneyfication of New Orleans to the 'whitewashing' of the city through rebuilding on higher ground in historic areas of the city that happen to be predominantly white. Despite such attention, there are a few media 'silences' that are worthy of note.

One area of the city that did receive ample media attention was the Lower Ninth Ward, a predominantly poor and working class black community. Much of this historic neighborhood was inundated from a breach in the canal walls connecting the Mississippi River to Lake Pontchartrain. The houses situated closest to the breach were literally washed away and thus unsalvageable, but the remainder of the housing stock has been subject to much debate.

According to Elizabeth English, a construction engineer at Louisiana State University's Hurricane Center, most of these houses were built appropriately for a floodplain. They were constructed of mold- and rotresistant cypress wood, raised two to four feet off the ground on piers, and built to flood and drain. 'Many of the houses that are good candidates for recovery have been labeled $52 \%$ or $56 \%$ damaged by FEMA,' says English. ${ }^{4}$ In order for a homeowner to get a building permit, and thus compensation from FEMA and a private insurance company to rebuild, the house must have sustained less than $50 \%$ damage. According to engineers and community activist groups, FEMA's experts not only have overstated damage, but in some cases have allowed further damage to occur through inaction. For example, FEMA would declare $100 \%$ roof damage when the actual damage was very slight, meaning that the agency would not provide blue plastic material to protect the roof, allowing rain to further damage the property.

To challenge FEMA's damage determination, a homeowner must be present in New Orleans and show evidence contradicting the damage determination. This is difficult for the many residents currently living in Houston or Atlanta who have no way to file a grievance. Furthermore, assembling a counter-claim to the damage assessment is complicated and deters many poor owners. In adjacent mostly white Jefferson Parish, many neighborhoods have streets full of houses with small FEMA trailers in their 
yards, enabling owners to rebuild while living on site. Few such trailers can be found in Orleans Parish. Many neighborhoods in that parish still have no electricity or water, and so the trailers would be of little use, and residents have nowhere to live while repairing their homes. The longer they stay away, the less likely is their return.

When inner city 'flight' happened in the late 1960s through the 1970s, the white middle class population was the first to move west across parish lines to Jefferson Parish. A decade or so later, many of the black middle class moved to east Orleans Parish, then a sparsely inhabited marshy peninsula comprising approximately $25 \%$ of the total parish landmass. While the plight of the Lower Ninth Ward has received ample press, New Orleans East (as this neighborhood is called) has been invisible. This was one of the last sections of the city to open after the flooding, and to date it has not had infrastructural services restored. The houses and apartment buildings in this large area of the city are still very much intact, after having suffered a tidal surge that was less devastating than the flooding of the Ninth Ward. Miles of suburban homes, with slab-on-grade foundations inappropriate for floodprone areas, now sit vacant in Orleans East, raising questions about the fate of a large number of New Orleans' black middle class. Social factors and de facto segregation once led to the development of that suburb on low-lying ground. Should floodplain construction engineering dictate the removal of these homes, because they would be difficult to protect from future flooding, or should race and the history of segregation play a part in repatriation? What would a remedy look like and who is financially responsible?

Another 'silent' issue was brought to light when New Orleans' mayor Ray Nagin unveiled the rebuilding plan developed by his 'Bring New Orleans Back Commission' in consultation with the Urban Land Institute and other non-governmental organizations (NGOs). ${ }^{5}$ The plan organized the city into four zones: immediate rebuilding, building moratorium, targeted for new development, and proposed new parks (drainage). Typically these zones followed the flood maps, with unflooded areas slated for immediate rebuilding and historically important flooded areas targeted for new development. A building moratorium was put on badly flooded areas, with some being set aside for new parks that would serve as flood control areas. Notable exceptions were several poor, predominantly black, neighborhoods near downtown along the river from the Lower Garden District to the Irish Channel. These neighborhoods are located on high ground that was not flooded. The seemingly objective taxonomy of land elevation and reconstruction raises the question of a possible social subtext: Why would poor African American communities that were not flooded be targeted for redevelopment when similarly dry white middle and upper class communities were slated for immediate rebuilding?

\section{Conclusion}

The hurricane, a natural disaster, was a social and technological disaster, providing a lesson in environmental justice that expands beyond Katrina 
and New Orleans. Social factors, such as race, class, culture, and education level are important to consider when devising equitable plans for cleanup, rebuilding, and resettlement in the aftermath.

In the past, EJ struggles that demanded buyout and resettlement were less likely to be successful than those that asked for non-displacing solutions (Toffolon-Weiss \& Roberts, 2005). This may indicate good prospects for poor and minority communities in New Orleans that are requesting cleanup and restoration of their homes and neighborhoods, but of course, previous EJ issues may not easily map onto the current situation, given the magnitude of the disaster.

My own research on the EJ movement in Louisiana has shown that the strongest citizens' groups form alliances with well-organized national and multi-national environmental and social justice groups, enroll the support of activist and independent scientists and professional experts, and include members from diverse social classes and ethnic groups (Allen, 2003). Alliances with national groups are being formed and the media attention given to New Orleans has made the struggles of displaced citizens highly visible. Slowly, more independent scientists and experts are participating in the environmental debate on behalf of citizens who otherwise might not have access to corporate and government experts. Public trust in scientific and technological claims will be important in the rebuilding effort, and it is also important for outside experts to be heard, so that state economic and/or political interests will not override community health and well-being. Portrayed as 'objective', expert reports are embedded with values and agendas sometimes not shared by residents. More could be done to involve citizens with scientists who are asking questions aligned with local interests.

Finally, the segregation of New Orleans, and the correlation between race and elevation involved in the rebuilding plans, may make it difficult for citizen groups to attain the heterogeneity that has led to success in previous EJ disputes. As rebuilding plans progress, community leaders might give some consideration to alliances between adjacent communities with different demographics. This would enable them to build upon diverse social capital and to push for common objectives. Of course, this strategy presupposes that diverse neighborhoods will be able to congregate and make common decisions. This would be especially difficult for dispersed residents of destroyed neighborhoods, and remains one of the largest problems faced by victims of Hurricane Katrina.

\section{Notes}

1. My information about the floodwaters was taken from two interviews: Wilma Subra, self-employed environmental scientist, interviewed on 25 January 2006 at her office in New Iberia, Louisiana, and Ivor van Heerden, coastal geologist, LSU Hurricane Center, interviewed on 6 February 2006 in Washington, DC.

2. The environmental data that Wilma Subra and other scientists have collected in the aftermath of Hurricanes Katrina and Rita is available at

<www.leanweb.org/katrina/katrinadata.html> (accessed 22 February 2006).

3. From an interview with Elizabeth English on 'To the Point', National Public Radio, 13 January 2006. 
4. From a phone interview I conducted with Elizabeth English on 17 February 2006.

5. For a complete set of reports, see the 'Bring New Orleans Back' website at $<$ www.bringneworleansback.org/>

\section{References}

Allen, Barbara L. (2003) Uneasy Alchemy: Citizens and Experts in Louisiana's Chemical Corridor Disputes (Cambridge, MA: MIT Press).

Allen, Barbara L. (2004) 'Shifting Boundary Work: Issues and Tensions in Environmental Health Science in the Case of Grand Bois, Louisiana', Science as Culture 13(4): $429-48$.

Allen, B.L. (2005) 'The Problem With Epidemiology Data in Assessing Environmental Health Impacts of Toxic Sites', in M.M. Aral, C.A. Brebbia, M.L. Maslia \& T. Sinks (eds.), Environmental Exposure and Health (Boston, MA: WIT Press): 467-75.

Irwin, Alan, Alison Dale \& Denis Smith (1996) 'Science in Hell's Kitchen: The Local Understanding of Hazard Issues', in A. Irwin and B. Wynne (eds.), Misunderstanding Science? The Public Reconstruction of Science and Technology (New York: Cambridge University Press): 47-64.

Roberts, J. Timmons \& Melissa M. Toffolon-Weiss (2001) Chronicles from the Environmental Fustice Frontline (New York: Cambridge University Press).

Toffolon-Weiss, Melissa M. \& Timmons Roberts J. (2005) 'Who Wins, Who Loses? Understanding Outcomes of Environmental Injustice Struggles', in D. Pellow \& R. Brulle (eds.), Power, Fustice, and the Environment (Cambridge, MA: MIT Press): $77-90$.

Barbara L. Allen is the Director of the Graduate Program in Science and Technology Studies at Virginia Tech's Washington DC area campus. She is author of the book Uneasy Alchemy: Citizens and Experts in Louisiana's Chemical Corridor Disputes (2003), as well as numerous papers on environmental justice and Hurricane Katrina.

Address: Department of STS, 1021 Prince St, Room 206, Virginia Tech, Alexandria, VA 22314, USA; tel: +1 703706 8115; fax +1 703518 8009; email: ballen@vt.edu 